\title{
The node of Ranvier in CNS pathology
}

\author{
I. Lorena Arancibia-Carcamo • David Attwell
}

Received: 17 April 2014 / Revised: 27 May 2014 / Accepted: 27 May 2014 / Published online: 10 June 2014

(C) The Author(s) 2014. This article is published with open access at Springerlink.com

\begin{abstract}
Healthy nodes of Ranvier are crucial for action potential propagation along myelinated axons, both in the central and in the peripheral nervous system. Surprisingly, the node of Ranvier has often been neglected when describing CNS disorders, with most pathologies classified simply as being due to neuronal defects in the grey matter or due to oligodendrocyte damage in the white matter. However, recent studies have highlighted changes that occur in pathological conditions at the node of Ranvier, and at the associated paranodal and juxtaparanodal regions where neurons and myelinating glial cells interact. Lengthening of the node of Ranvier, failure of the electrically resistive seal between the myelin and the axon at the paranode, and retraction of myelin to expose voltage-gated $\mathrm{K}^{+}$channels in the juxtaparanode, may contribute to altering the function of myelinated axons in a wide range of diseases, including stroke, spinal cord injury and multiple sclerosis. Here, we review the principles by which the node of Ranvier operates and its molecular structure, and thus explain how defects at the node and paranode contribute to neurological disorders.
\end{abstract}

Keywords Neuron · Node of Ranvier - Sodium channel · Myelin

\section{Introduction}

Timely delivery of information is essential for the proper function of the nervous system. The increase in axonal

I. L. Arancibia-Carcamo · D. Attwell ( $₫)$

Department of Neuroscience, Physiology and Pharmacology, University College London, London WC1E 6BT, UK

e-mail: d.attwell@ucl.ac.uk conduction speed produced by myelination allows rapid transmission of electrical signals over large distances between neuronal cell bodies and their axon terminals, and thus confers improved cognitive function [44]. Precise regulation of this conduction velocity may allow tuning of motor skills and sensory integration [128, 147]. Consequently, any disruption, in pathology, of the two specialised structures that are essential for rapid conduction-the myelin sheath and the node of Ranvier-can be expected to alter sensory perception, cognitive processing and motor output. Numerous articles have reviewed the malfunctions which stem from loss of the myelin sheath in disorders such as multiple sclerosis, stroke, spinal cord injury and cerebral palsy [44, 94, 95, 134, 146]. However, despite its importance, pathological disturbances of the node of Ranvier (and its surrounding domains) have received far less attention. Here we aim to redress this situation (see also [139]), because recent studies have highlighted structural changes at the node of Ranvier and altered function of proteins at this site as key players in neuronal dysfunction.

\section{Myelin and the node of Ranvier}

Saltatory conduction along myelinated axons evolved in vertebrates as a way of rapidly transmitting electrical impulses across large distances. The axon down which the action potential travels is wrapped by myelin, which is produced by oligodendrocytes in the central nervous system (CNS) and by Schwann cells in the peripheral nervous system (PNS). This myelin sheath increases the effective resistance of the axonal membrane, lengthening its electrical space constant and thus promoting signal spread along the axon. More importantly [7], however, myelin decreases the effective capacitance of the axonal membrane, so that 

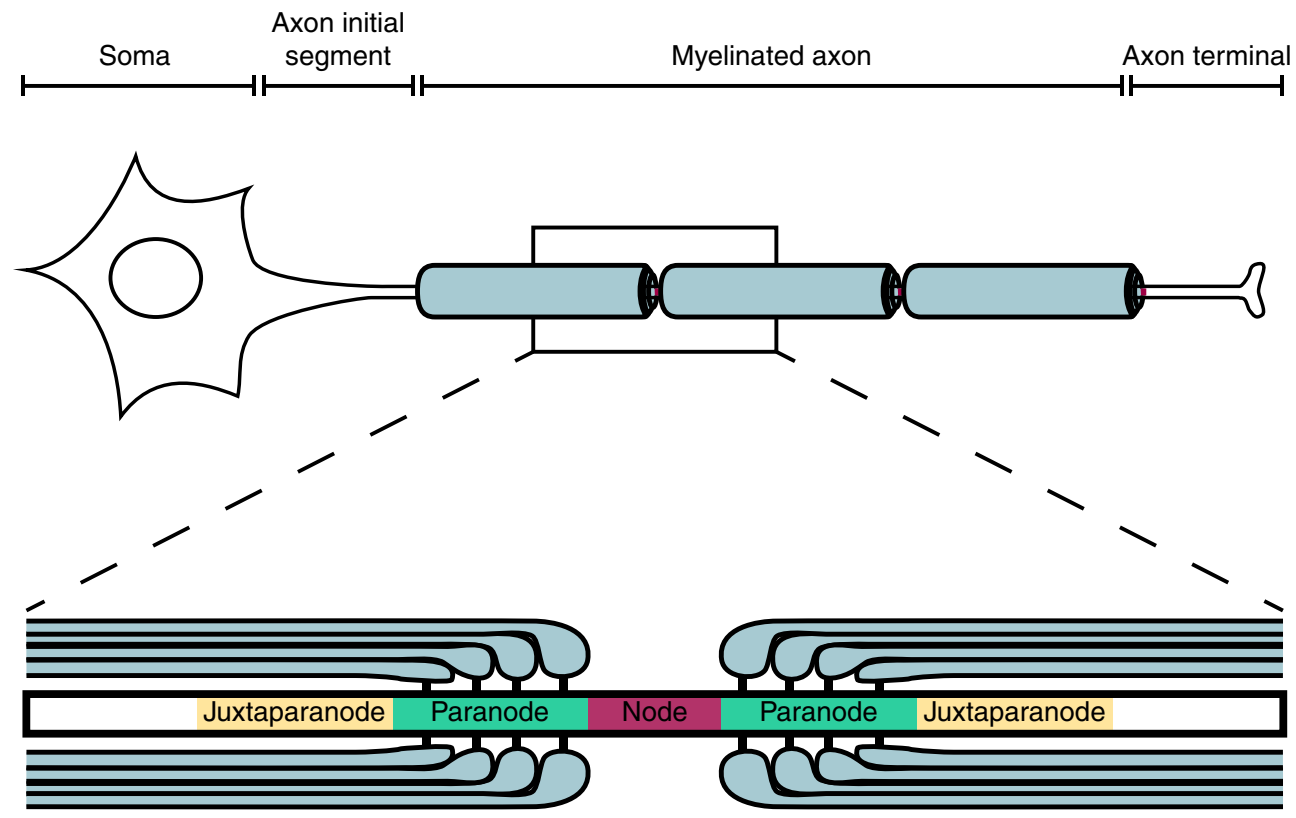

Fig. 1 Schematic diagram showing the different domains of a myelinated neuron. The axonal region around the node of Ranvier is expanded to show the different axonal domains: the node of Ranvier where voltage-gated $\mathrm{Na}^{+}$channels are expressed, the paranode where the myelin is attached to the axon, and the juxtaparanode where most voltage-gated $\mathrm{K}^{+}$channels are located. Each of these domains is characterised by the expression of specific proteins (shown in Fig. 2) less charge (in the form of $\mathrm{Na}^{+}$) needs to enter to depolarize the cell. Both of these effects increase the action potential conduction speed. In addition, the reduction of $\mathrm{Na}^{+}$entry leads to less ATP being used by the axon on $\mathrm{Na}^{+}$pumping, thereby allowing the conduction of the action potential to be more energetically efficient for the axon, at the expense of more energy being used to maintain the resting potential of the ensheathing oligodendrocyte [55].

Fundamental to the function of myelinated axons is the existence of discrete sites where $\mathrm{Na}^{+}$enters to generate the action potential: the nodes of Ranvier are small ( $1 \mu \mathrm{m}$ long) regions along myelinated axons where there is a break in the myelin sheath and the axon membrane is in contact with the bulk extracellular space, allowing $\mathrm{Na}^{+}$ entry through voltage-gated channels (Fig. 1). In order for nodes to form and function correctly, highly complex interactions are needed between the axon and its ensheathing glial cell. These interactions have four functions. They serve to: (1) define the node as an area free of the glial sheath, (2) localise voltage-gated $\mathrm{Na}^{+}$(Nav) channels in the axonal membrane at the node, (3) localise axonal $\mathrm{K}^{+}$ channels on either side of the node, and (4) attach the ends of the myelin sheaths to the axon on either side of the node so that current cannot easily pass under the myelin (which would negate its membrane capacitance-reducing and resistance-increasing effects). A large array of scaffolding and cell adhesion proteins is required to mediate these axon-glial interactions (Fig. 2), and the complexity of the protein-protein interactions involved makes the structure of the node and surrounding regions prone to disruption in pathological conditions.

To understand how nodal function may be disrupted in disease, we need to understand the electrical principles by which the node operates, how it is formed and the molecules which are essential for its function.

\section{Electrical principles for healthy node of Ranvier function}

Four general principles must be obeyed if the node of Ranvier is to function correctly. Firstly, the molecular mechanisms described below must produce a high concentration of Nav channels in the nodal membrane, where they will experience the full transmembrane voltage change of the action potential. This is needed for rapid activation of the channels. Any channels that are mislocalised to internodal regions, where they are covered with multiple layers of myelin, will experience a smaller voltage change and activate less, and more slowly, because in the internode the voltage change of the action potential $(\sim 100 \mathrm{mV})$ will be spread across $2 N+1$ membranes (where $N$ is the number of myelin wraps), resulting in axonal channels experiencing a depolarization of only $100 /(2 N+1) \mathrm{mV}$ or around $9 \mathrm{mV}$ for a typical CNS axon with $N=5$ wraps. In addition to being localised at the node, there needs to be a 


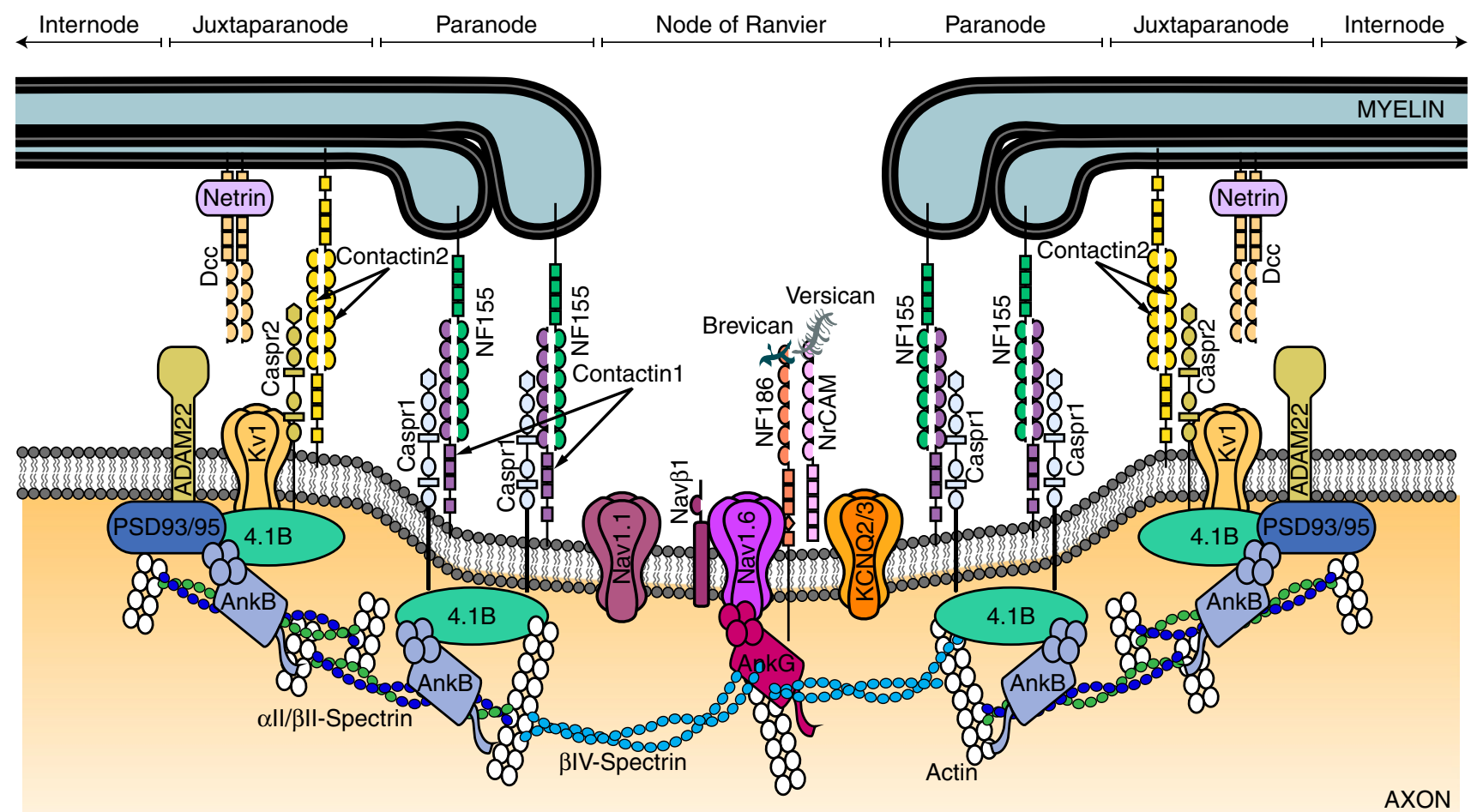

Fig. 2 Schematic diagram of the proteins at the node of Ranvier, paranode and juxtaparanode. These domains are the location of ion channels (Nav1.6 and Nav1.1, KCNQ2/3, Kv3.1 and Kv1.1/1.2), cell adhesion molecules (neurofascin 155 (NF155), neurofascin 186 (NF186), contactin 1 and 2, contactin-associated protein (Caspr 1 and 2), cytoskeletal scaffolding proteins [Ankyrin (Ank) G and B, protein

sufficient number of Nav channels at the node to generate enough current to depolarise the next node along the axon: a decrease of the number of functioning Nav channels may cause propagation failure.

Secondly, most voltage-gated $\mathrm{K}^{+}$channels (Kv1 type, see below) are localised to the juxtaparanodal region (Fig. 2) [47, 112], although Kv3.1b channels and slowly activating KCNQ (also known as Kv7) channels are present at the node itself $[32,34]$. Placing $\mathrm{K}^{+}$channels in the juxtaparanode under the myelin sheath will reduce the voltage they experience, and hence reduce their activation under normal conditions, for the reasons described above. However, the exact degree of activation occurring will depend on how much current flow can occur under the myelin to the juxtaparanodal region, to maintain the extra-axonal voltage close to the bulk extracellular value of $0 \mathrm{mV}$. The application of 4-aminopyridine (4-AP, which blocks Kv1 type channels) has little effect on the propagation of single action potentials (bursts of action potentials were not tested) in dorsal column axons [76] and similarly knockout of Kv1.1 produces only a small prolongation of the
4.1B, and postsynaptic density protein 93/95 (PSD93/95)], cytoskeletal proteins ( $\beta \mathrm{II}-$ and $\beta \mathrm{IV}$-spectrin), and extracellular matrix proteins (brevican, versican and a secreted form of NrCAM). Targeting and scaffolding mechanisms ensure that each protein is segregated to its specific subdomain

action potential in PNS axons [132]. However, more variable effects of 4-AP were reported in optic nerve axons, with Foster et al. [45] reporting relatively minor effects (compared to those on unmyelinated axons) while Devaux et al. $[32,33]$ found a profound broadening of the action potential, suggesting that these channels contribute different amounts to action potential repolarization in different axons. Although Kv3.1b channels are also blocked by 4-AP (unlike KCNQ channels), the action potential broadening that 4-AP produces in optic nerve axons is still seen with Kv3.1b knocked out [32] implying that 4-AP has its effect by acting on Kv1 channels. Furthermore, during node development, at least in the PNS, these channels prevent re-entrant excitation of the nodes following single impulses [148].

Thirdly, for the myelin to reduce the effective axonal membrane capacitance well, there needs to be little current flow under the myelin sheath $[6,120]$. As described below in the description of the molecular apparatus at the paranode, this current flow is reduced by the formation of adhesive junctions between the ensheathing glial 


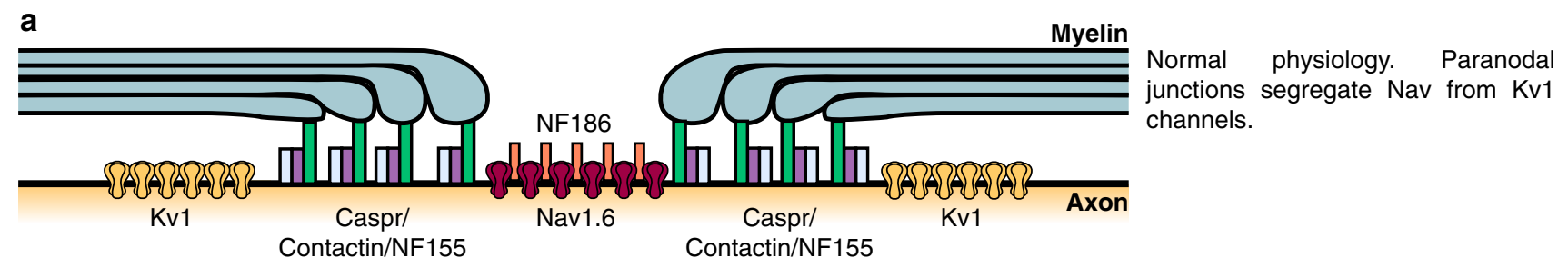

b

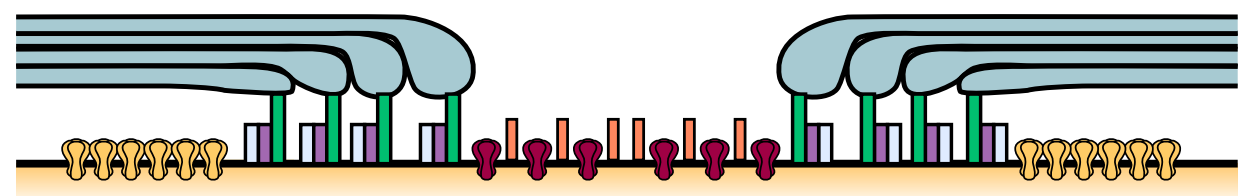

Neonatal hyperoxia. Node elongation without disruption of the paranodal junction [118].
C

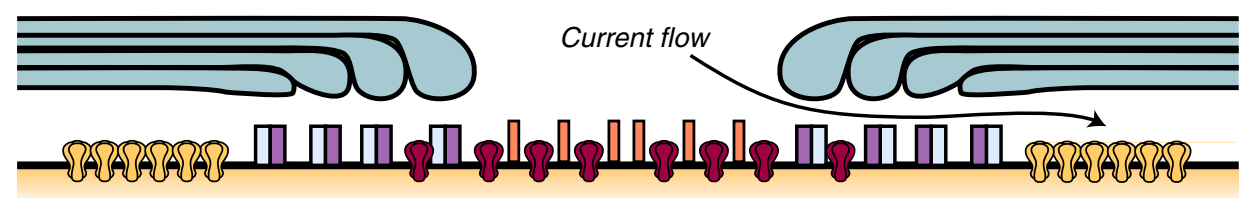

Multiple sclerosis, cerebral hypoperfusion and inhibition of ATP production. Node elongation with a loss of NF155 may allow extracellular current flow to juxtaparanode. $[64,88,114]$. d

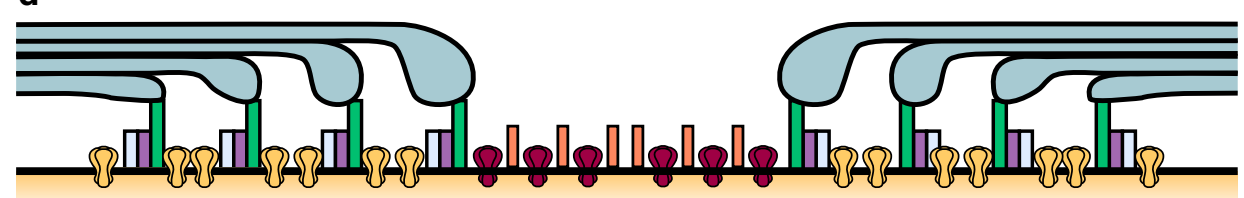

Multiple sclerosis and ageing. Node and paranode elongation with redistribution of $\mathrm{Kv} 1$ into paranode. $[60,64]$

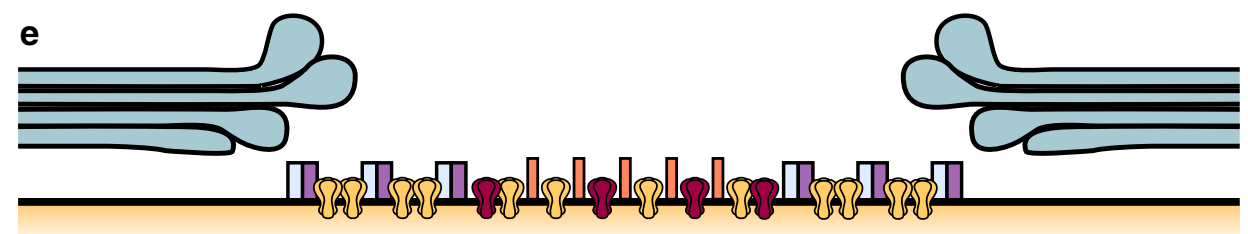

Multiple sclerosis, EAE, glutamate excitotoxicity, and spinal cord injury. Myelin retraction, paranodal loop eversion, node lengthening and mixing of Nav, Kv1 and Caspr. $[47,48,64,101,138]$.

Fig. 3 Cartoon illustrating potential mechanisms underlying enlongated nodes of Ranvier in different pathologies. a Diagram of the nodal region in control conditions. Nav channels and Kv1 channels are segregated by paranodes. b In neonatal hyperoxia, nodes of Ranvier are enlarged without any observed disruption of the paranodal junction. c In multiple sclerosis, cerebral hypoperfusion and in an experimental model of energy deprivation, the node of Ranvier is enlarged, there is a loss of NF155, and Nav channels slightly overlap with the paranodal protein Caspr. The disruption of the paranodal junction may allow current flow to under the myelin sheath to pro-

cells and the axon. However, these septate-type junctions still leave a spiral pathway between the extracellular space at the node and the extracellular space at the juxtaparanode [120], through which some current may flow to allow mote the activation of Kv1 channels at the juxtaparanode, thereby compromising action potential firing. $\mathbf{d}$ In the ageing brain and in multiple sclerosis, an elongation of the paranode can be caused by a separation of the paranodal loops. This is accompanied by a redistribution of $\mathrm{Kv} 1$ channels into the paranodal area, where they overlap with Caspr and NF155. e Myelin retraction, and a breakdown of the molecular organisation of the node of Ranvier, paranode and juxtaparanode, are observed in multiple sclerosis, EAE, glutamate excitotoxicity, and spinal cord injury

partial activation of juxtaparanodal $\mathrm{K}^{+}$channels. During pathology, as described below, disruption of the paranodal structure may loosen this junction, leading to more extracellular current flow beneath the sheath (Fig. 3c) and more 
activation of the juxtaparanodal $\mathrm{K}^{+}$channels, which may prevent action potential propagation, especially during repeated firing.

Fourthly, the nodal length and diameter need to be controlled. The speed with which nodal Nav channels activate is partly determined by the capacitance of the node, and hence by its membrane area $[6,153]$. An increase in area, as occurs in some pathologies (see below), will tend to slow the action potential (unless extra Nav channels are inserted into the membrane to oppose this effect). Furthermore, an increase in node length, as also occurs in pathology, will increase the axial resistance for the current flow from the node to the internode that is needed to depolarise the next node, again slowing the action potential, or even causing it to fail.

Below, we will relate the molecular organisation of the nodal components, and the changes that occur in pathology, to these principles of nodal function.

\section{Molecular organisation of the node of Ranvier}

As mentioned above, the node of Ranvier needs a high density of Nav channels to function correctly, and also has some Kv channels which (by controlling the resting potential and Nav channel inactivation) are thought to regulate the amount of current that the Nav channels generate [9]. In the CNS, the Nav channel isoforms found at nodes of Ranvier are Nav1.6, Nav1.1 and (earlier in development) Nav1.2 [35, 117]. Despite its small size $(\sim 1 \mu \mathrm{m})$, the node of Ranvier is a densely populated area of the axon, with a large number of cytoskeletal scaffold proteins and transmembrane adhesion proteins, all of which help to recruit and maintain the Navs at this site. PNS and CNS nodes have the same function, however, they differ slightly in structure and the mechanisms for their assembly are different $[141,158]$. The biggest structural difference is that in the PNS, the nodes of Ranvier are apposed by nodal microvilli emanating from myelinating Schwann cells. These microvilli may play a role in local ion buffering, but also express gliomedin, a glial protein known to be important for the clustering of Nav channels at PNS nodes of Ranvier (for more information on PNS nodes of Ranvier see [13, 122]). Although CNS nodes of Ranvier are not contacted by protrusions of oligodendrocytes, they are often closely associated with astrocytic processes, the function of which remains unknown $[58,59]$.

The clustering of Nav channels at nodes of Ranvier is mediated by the scaffolding protein ankyrin G (Fig. 2). Ankyrin $\mathrm{G}$ is a large protein with various protein-binding domains that simultaneously connect a number of proteins at the node to the cytoskeleton (although ankyrin $G$ has also been observed, albeit at much lower levels, localised to paranodes where it has an unknown role [111]). In addition to Nav channels ankyrin $G$ has been shown to bind KCNQ channels, the adhesion protein neurofascin 186 (NF186) and cytoskeletal spectrins. This ability to bind the transmembrane protein NF186 and simultaneously bind the spectrin-based cytoskeleton is what allows ankyrin $\mathrm{G}$ to behave as a scaffold maintaining Nav and KCNQ channels at the nodes of Ranvier [and at the axon initial segment (AIS), where all these proteins are also found] $[109,110]$. It has recently been shown that ankyrin $G$ is transported down the axon to the nodes of Ranvier via a direct interaction with kinesin 1 [8]. Importantly, Nav channels are cotransported with ankyrin $\mathrm{G}$, suggesting that ankyrin $\mathrm{G}$ is not only critical for the stabilisation of Navs at the node of Ranvier but also crucial for the correct subcellular targeting of these channels [8]. Ankyrin $\mathrm{G}$ is recruited to the nodes as a result of a direct interaction with NF186. NF186 plays an important role in the assembly and maintenance of the node of Ranvier via its interactions with the extracellular matrix components brevican, versican and a secreted soluble form of $\mathrm{NrCAM}$, as well as via the aforementioned interaction with ankyrin G [31, 141]. NF186 may also play a role in the function of the node as it has recently been shown to be important for nodal expression of the Nav channel accessory beta1 subunit, which modulates Nav function [21,31].

\section{Pathologies of the node of Ranvier}

Although small changes at the node of Ranvier can have large effects on the speed of action potential propagation, it is only in the last decade that disruption of this site in pathology has been investigated in depth.

The correct function of nodal Nav1.6, Nav1.1 and KCNQ channels is important for saltatory conduction along myelinated axons. Alteration of the electrical excitability, permeability or expression of Nav1.6 or Nav1.1 channels can result in autism, epilepsy syndromes, periodic paralysis, or fibromyalgia (reviewed in [37]). Similarly, mutations in KCNQ2 and KCNQ3 channels result in benign familial neonatal convulsions and myokymia (spontaneous muscle quivering), highlighting their importance in controlling excitability [87]. However, given that these channels are not only expressed at CNS nodes, but also at the AIS and, to a lesser extent, somatodendritic compartments [34, 81, 84,149 ], further work is needed to establish whether it is the defects in the function of these channels at the node of Ranvier that are responsible for these disorders.

Quivering 3J mice, which show a frame-shift base insertion in the Sptnb4 gene encoding $\beta I V$-spectrin and thus lack the $\mathrm{C}$-terminus of $\beta \mathrm{IV}$-spectrin, display neuromyotonic and myokymic discharges similar to those observed in mice with KCNQ2 mutations. Axons in the quivering 3J mice 
were properly myelinated and displayed proper targeting of Nav channels, Caspr and contactin, and Kv1 channels to the nodal and surrounding regions. However, despite KCNQ protein levels being unaffected overall in the brain, KCNQ channels were not found at either CNS or PNS axon initial segments or nodes of Ranvier, suggesting that the $\mathrm{C}$ terminal of $\beta I V$-spectrin is essential for correct localization of these channels to the Ranvier node and AIS.

An increase in the length of the node of Ranvier (defined by $\mathrm{NaV}$ or NF186 immunolabelling) has been observed in multiple sclerosis [64], experimental autoimmune encephalomyelitis (EAE) [47], ageing [60], cerebral hypoperfusion [114], inhibition of mitochondrial ATP production [88], spinal cord injury [101, 138], glutamate application to mimic its release in excitotoxic disorders [48], neonatal hyperoxia [118], and exposure to loud sounds [142] (Fig. 3). It has been suggested that this lengthening is due to myelin retraction and a breakdown of the paranodal junction (Fig. 3c, e), leading to a redistribution of $\mathrm{Kv}$ channels and current flow under the myelin sheath [48, 101] (see below). However, in some of these conditions it is possible that the node lengthens (giving the appearance of myelin retraction) whilst maintaining intact paranodal and juxtaparanodal structures (Fig. 3b) because there is an insertion of more membrane at the node, or lengthens due to a withdrawal from the axon of paranodal loops immediately adjacent to the nodal domains (adnodal paranodal loops). In this case, juxtaparanodal $\mathrm{Kv}$ channels may not be abnormally activated, but the increase of nodal surface area would lead to an increased nodal capacitance and, unless more Nav channels were inserted, a reduction of the action potential conduction velocity. A conduction velocity decrease has been observed in a number of transgenic mice in which some axons have normal nodal Nav channels, internodal myelin and transverse bands (a prominent component of the paranodal junctions), but exhibit an eversion of paranodal loops adjacent to the node, resulting in small but significant increases in nodal length $[13,16,36,61$, 119]. The exact mechanisms involved in regulating changes in nodal length, however, are yet to be determined.

Intriguingly, altered neuronal activity can increase the length [78] and alter the position [42, 52] of the axon initial segment, which has molecular similarities to the node of Ranvier. However, it is not known whether similar molecular pathways underlie the increase of node length that occurs in pathology, nor whether alterations of node positions occur in the disorders mentioned above.

Subtle changes at the nodes which result in a failure of saltatory conduction may contribute to psychiatric disorders. Recent imaging studies in patients with schizophrenia $[28,96]$, bipolar disorder $[2,144]$, autism $[4,105]$ and personality disorder [86] have identified abnormalities in white matter integrity. Although the molecular basis for disease onset remains unknown, recent studies in schizophrenic and in bipolar patients have identified changes in nodal proteins. For example, microarray-based gene expression analysis across all brain regions of post-mortem brains from schizophrenia patients revealed a significant decrease in the expression of ankyrin $\mathrm{G}$ and neurofascin when compared to control tissue [121]. Furthermore, in the same study, analysis of the superior temporal gyrus, a region that has been shown to be altered in schizophrenia patients, found a significant downregulation of genes encoding for $\mathrm{NrCAM}$ and Nav1.6 in addition to neurofascin and ankyrin G [121]. Genome-wide association studies have found ANK3 (the gene encoding ankyrin G) to be a susceptibility gene for schizophrenia, and associated identified single nucleotide polymorphisms (SNPs) with bipolar disorder [5, 10, 43, 121, 125, 127]. Moreover, a different study found an epistatic interaction between ANK3 and KCNQ2 SNPs in bipolar disorder, i.e. the effect of a mutation in one gene was dependent on the mutation present in the other gene [72]. Given that these proteins are all found at high densities in the nodes of Ranvier as well as the AIS, it is possible that subtle abnormalities at these sites could affect action potential propagation and synchronicity of neuronal firing. ANK3 has also been identified as a susceptibility gene in other disorders such as autism [14], attention-deficit/hyperactivity disorder (ADHD) [66, 80], intellectual disability [66] and epilepsy [70]. Although the nodes of Ranvier have not been directly investigated in these disorders, the importance of ankyrin $\mathrm{G}$ in node development and stability pinpoints this region as a promising new area to consider when investigating the molecular basis of psychiatric disorders.

\section{Molecular organisation of the paranode}

The CNS node of Ranvier is defined by its flanking axooligodendroglial interactions which form the paranodes. Here, folds of uncompacted myelin interact directly with the neuronal axolemma, forming septate-like tight junctions. Although in vitro it has been shown that the paranodal junction is not a requisite for myelination [82], its formation is thought to be the first step in the development of nodes of Ranvier [141].

The paranode plays three important roles. Firstly, it acts as a diffusion barrier that separates the Nav channels in the node of Ranvier from the Kv1 channels in the juxtaparanodes. Studies on the AIS, which strongly resembles the node of Ranvier, in particular on the first paranodal junction at its distal end, have given insight into this. At this junction, the cytoplasmic proteins ankyrin-B, $\alpha$ II-spectrin and $\beta$ II-spectrin define an intra-axonal boundary that precedes the presence of ankyrin G, which it localises in the developing AIS [157]. In addition, protein 4.1B is involved in the segregation of 
molecules between the AIS and the first myelin segment. Because of the similarity of the AIS to the node of Ranvier, it is generally assumed that the role of the paranode at the interface of the AIS and the first internode must be similar to its role when flanking the node of Ranvier.

Secondly, the paranode is required for "glueing" the myelin to the axon and ensuring a tight connection between the myelin and the axolemma. This is not only important for restricting membrane proteins to the node of Ranvier, but also for reducing current flow under the myelin sheath (see "Electrical principles for healthy node of Ranvier function" section above). The strong interaction between myelin and the axolemma is achieved by a complex of three proteins: axonal contactin- 1 and contactin-associated protein 1 (Caspr1) and oligodendrocyte NF155. Knockout experiments in mice have shown that a deficiency in any of these proteins results in disruption of the axon-oligodendrocyte septate-like junctions which, in turn, causes axonal damage, slower nerve conduction and severe neurological defects, including ataxia and motor paresis, and death [13, 16, 49, 106, 129, 158]. Caspr1 and contactin-1 were first identified as neural adhesion molecules, which form a complex targeted to the paranodal junctions during myelination [39, $74,103,104,116]$. Shortly thereafter, NF155 was identified as the first glial component of the axo-glial paranodal junction [20, 143]. Contactin-1 and NF155 are similar in structure, both containing six immunoglobulin (Ig) domains and four fibronectin type III domains, but it is through the Ig domains that they are thought to interact with each other and with Caspr1. In turn, Caspr1 has a small cytoplasmic tail which contains a binding motif for the scaffold protein $4.1 \mathrm{~B}$, and this interaction is important for stabilisation of the Caspr1/contactin-1/NF155 complex at the paranode. The formation and maintenance of paranodal junctions are not only reliant on the Caspr1/contactin-1/NF155 complex, but also on GPI-anchored proteins, lipid raft-associated proteolipids and gangliosides, myelin galactolipids, as well as netrin and its receptor Dcc, which all play a role in the maintenance of the paranode, although the underlying mechanisms are poorly understood $[56,67,68,79,99,108,124,140]$.

Thirdly, using electron tomography Nans et al. [92] suggested a role for the paranode in directing protein traffic to the nodes. They identified an extensive network of filamentous linkers in the paranodal axoplasm connecting the juxtaparanode, the paranode and the node of Ranvier to each other, and showed that transport vesicles were tethered to the paranode by short filaments [92].

\section{Pathologies of the paranode}

Given the complex molecular anatomy needed at the paranode to maintain the association between myelin and axons
(Fig. 2), it is not surprising that it is a vulnerable structure in demyelinating disorders. Multiple sclerosis (MS) is a complex disease characterised by the demyelination of CNS axons affecting multiple parts of the brain and spinal cord, and leading to visual loss, paraesthesia, numbness, paralysis and other deficits. Although oligodendrocyte death plays a large part in the aetiology of MS, a number of studies have suggested that a disruption of the paranodal junctions may happen early in the onset of the disease. Post-mortem analyses of patients with multiple sclerosis show a disruption of the molecular organisation at the paranodes [24, 27, 64, 154] with decreased expression of Caspr and NF155 perhaps as a result of degradation [85, 154], and studies in an experimental model of MS (EAE) have shown that paranodal domain injury precedes the formation of internodal demyelinating lesions [47].

Several pathological conditions, including spinal cord injury $[15,69,93,130]$, demyelination caused by the shiverer mutation [131], multiple sclerosis and EAE [47, 64, 65], and glutamate application [48], result in paranodal disruption and a retraction of the myelin sheath. This produces an elongated appearance of the node of Ranvier as described above, and a movement of 4-AP-blockable Kv1 channels (which are normally found under the myelin sheath in the juxtaparanode, see below) closer to the elongated node (Fig. 3c-e) [64]. In some cases, the channels move out from under the myelin sheath so that they become more activated $[15,48,69,93,131]$ (see "Electrical principles for healthy node of Ranvier function" section above), which will tend to oppose impulse propagation, especially during repetitive activity. Consistent with the loss of the barrier function of the paranode, preventing proteins moving from the node into the internode, post-mortem analyses of MS patients show a diffuse expression of Nav channels along the demyelinated axons in white matter lesions [26, 91]. In demyelinating regions, NF155 immunolabelling shows an increase in the length of the paranodal regions [64], suggesting a separation of the paranodal loops (Fig. 3d). It is therefore likely that disruption of the clustering of nodal proteins participates in the conduction and locomotor deficits occurring in MS patients. Similarly the alterations of the paranodal axo-glial junctions, and the exposure from under the myelin of Kv1 channels described above, might contribute to the conduction defects. In agreement with this, blockade of Kv1 channels using 4-AP (known clinically as fampridine) is a clinically approved approach to improve motor deficits and vision in patients with spinal cord injury and multiple sclerosis $[15,51,63$, 93, 126, 130] (reviewed by [57, 71]).

The mechanisms responsible for the alterations in the paranodes and nodal regions in MS have not yet been resolved, although new research is beginning to build a picture of the steps involved. MS is thought to be an 
autoimmune inflammatory disorder leading to demyelination and neurodegeneration. In agreement with this, antibodies to myelin have been identified in patients with MS $[12,115,136,137,150,155]$. Interestingly, antibodies to the nodal and paranodal proteins NF155 and NF186 have also been observed in a subset of MS patients [41, 89], and these patients respond well to intravenous Ig injection and plasma exchange to remove the antibodies. A causal role for neurofascin antibodies in disrupting axonal conduction in a complement-dependent manner was corroborated by in vitro experiments applying the antibodies to hippocampal slice cultures [89]. Complement is a signal for attack by CNS microglia, and it has been shown that, independent of demyelinating lesions, there is a correlation between an increased microglial density and disruption of the paranodes in MS [65]. Furthermore, the elongation of paranodes observed in EAE mice can be blocked by preventing microglial activation with minocycline [65]. However, it is less clear whether microglial attack is involved in causing the paranodal disruption that occurs in spinal cord injury or with a raised extracellular glutamate concentration.

Intriguingly, disruption of the paranode has also been reported in ageing primates [60], with the movement of Kv1.2 channels from the juxtaparanode to the paranode where they are more likely to be activated as a result of better electrical coupling of the extra-axonal space to the extracellular space at the node. Conceivably, therefore, paranodal disruption could contribute to the cognitive decline that occurs in ageing.

\section{Molecular organisation of the juxtaparanode}

Adjacent to the paranodal region lies the juxtaparanode (Fig. 1). This part of the axon is directly under the compact myelin, but does not extend for the entire length of the internode. Juxtaparanodes are enriched in Shaker-type Kv1 channels with Kv1.1 and Kv1.2 being the most predominant forms $[112,113,148,151,152]$. The importance of this cluster of $\mathrm{Kv}$ channels in mature myelinated axons, however, remains somewhat contested since, as reviewed above (see "Electrical principles for healthy node of Ranvier function" section), in normal conditions the application of 4-aminopyridine (to block $\mathrm{Kv}$ channels) to different axon tracts can have little effect on action potential propagation $[45,76]$ or can significantly broaden the action potential $[32,33]$. Furthermore, at least in the PNS, whether $\mathrm{Kv}$ channels are clustered at the juxtaparanode or diffusely positioned along the internodes also seems to have little effect on the action potential propagation speed for single stimuli $[107,145]$. This may be because the conduction speed depends primarily on the initial depolarizing phase of the action potential and less on its repolarization phase. Alternatively, it may reflect the fact that, even when these channels are correctly located at the juxtaparanode, they are little activated by the small voltage change they experience there. Despite this, Kv channels are thought to promote the fidelity of conduction by maintaining the internodal resting potential and preventing activation of any Nav channels present in the internodal axonal membrane. They thereby maintain the temporal precision of action potentials and dampen repetitive firing. During PNS node development, Kv1 channels prevent re-entrant excitation of the nodes [22, 50, 75, 77, 148].

The accumulation of Kv1 channels at the juxtaparanode is dependent on the cell adhesion molecules contactin-2 (known as TAG-1 in rodents) and Caspr2 [53, 107, 145]. Although deletion of contactin-2 or Caspr2 prevents the accumulation of Kv1 channels at juxtaparanodes, so that they are diffusely expressed along the internodes, as described above this has little effect on the speed of nerve conduction when tested in the PNS [107, 145]. Contactin-2 and Caspr2 are homologous to the paranodal proteins contactin-1 and Caspr1, and form a heteromeric complex on the axonal membrane. In contrast to the paranode (where axonal contactin-1/Caspr1 binds to oligodendroglial NF155), the oligodendroglial binding partner to the contactin-2/Caspr2 complex is contactin-2, which is also expressed on the myelin sheath. Similar to what happens at the paranodes, contactin-2 and Caspr2 are stabilised at the juxtaparanodes via an interaction with the scaffolding proteins 4.1B, ankyrin-B, $\alpha$ II-spectrin and $\beta$ II-spectrin. All of these scaffolding proteins are also found at paranodes, suggesting that perhaps the segregation of paranodes and juxtaparanodes is in part accomplished by the different localisation of the glial adhesion molecules NF155 and contactin-2 $[19,23,30,38,62,100]$. Also found at the juxtaparanodes is the desintegrin and metalloprotease ADAM22, which is closely associated with Kv1 channels [98]. ADAM22 recruits the MAGUK scaffold proteins PSD-93 and PSD95 to the juxtaparanodes, but the exact function of this is unknown [98]. Intriguingly, in peripheral nerves ADAM22 is thought to play a role in controlling myelination via its interaction with a molecule secreted by Schwann cells, Lgi4 (leucine-rich glioma-inactivated 4) [102].

\section{Pathologies of the juxtaparanode}

Mutations in CNTN2 and CNTNAP2 (the genes encoding contactin-2 and Caspr2, respectively) have been identified in autism spectrum disorder, epilepsy, Tourette's syndrome, schizophrenia and ADHD [11, 40, 46, 90, 97, 135]. In the CNS, contactin-2 deletion leads to a loss of Kv1 clustering at juxtaparanodes, a reduction of internode length, and abnormalities of learning and memory, although it is 
unclear whether these are related to the paranodal and internodal alterations [123]. More recently it has been shown that, in addition to its role at the juxtaparanode, Caspr2 is expressed at synapses and involved in neural circuit assembly, and it has been suggested that it is a failure in this function that may underlie the effect of Caspr2 mutations on the development of autism [3].

Genetic mutations in Kv1 channels in humans, or depletion of the Kv1.1 gene in mice, result in hyperexcitability, episodic ataxia, myokymia and epilepsy $[1,17,18,25,29$, $83,132,156,160]$, consistent with a role for Kv1 channels in limiting action potential generation. However, Kv1.1 and Kv1.2 channels can also be found in the AIS and axon terminals, and deletion of the Kv1.1 gene produces only a small prolongation of the compound action potential in mature nerves [132], making its loss at the juxtaparanode an unlikely explanation for the dramatic phenotypes observed in humans and mice. A more plausible explanation was provided for the PNS by Chiu and colleagues [22] who suggested that Kv channels expressed at the juxtaparanode of the last few internodes, before the synaptic terminal, play an important role in regulating neurotransmitter release.

Juxtaparanodal $\mathrm{Kv}$ channels are thought, however, to play an important role in demyelinating pathologies, where (as noted above) loss of the integrity of the paranodal axon-oligodendrocyte junction results in exposure of these channels from under the myelin. This will lead to them experiencing a larger voltage change during the action potential (see "Electrical principles for healthy node of Ranvier function" section above), and generating a larger outward membrane current, which contributes to the loss of action potential propagation. Blockade of these channels using 4-AP is a current treatment for relieving the conduction defects in multiple sclerosis and other demyelinating diseases [15, 51, 54, 63, 93, 126, 130] (reviewed by [57, 71]). However, the occurrence of seizures prevents administration of the high doses of 4-AP that are maximally effective at promoting action potential propagation in demyelinating axons [71], and it has been suggested that the channels being blocked to improve function are not in the demyelinating axons but at synaptic terminals [133].

Auto-antibodies to Kv1 channels have been found to contribute to Morvan's syndrome and limbic encephalitis [73]. These frequently bind to juxtaparanodal $\mathrm{K}^{+}$channels, suggesting that block of these channels contributes to the symptoms of neuromyotonia (spontaneous muscle fibre activity), confusion, anxiety, agitation, delirium or insomnia seen in these patients.

\section{Conclusions}

Action potential propagation along myelinated axons is dependent on healthy nodes of Ranvier. A large and complex machinery has evolved to produce correctly functioning nodes of Ranvier by ensuring the correct targeting of Nav and $\mathrm{Kv}$ channels, the formation of tight junctions between paranodal loops and the neuronal axolemma, and the control of nodal length and diameter. Here, we have described the different domains which comprise the nodes of Ranvier and explained how changes at these sites underlie the variations in neuronal excitability observed in a number of neuropathologies. However, further work is still required to fully understand the molecular mechanisms that re-structure the node of Ranvier in disorders such as multiple sclerosis, ageing, spinal cord injury and neonatal hypoxia. In addition, proteins found at the node of Ranvier have been implicated in the pathology of psychiatric diseases such as schizophrenia, bipolar disorder, autism, personality disorder, ADHD and cognitive impairment, but it is still unclear whether the nodes of Ranvier and action potential propagation are indeed altered in patients with these disorders. Research into the basic mechanisms underlying the development, maintenance and disruption of nodes of Ranvier and paranodal junctions is likely to generate new therapeutic targets for neurological disorders of excitability.

Acknowledgments Supported by the Wellcome Trust and ERC. We thank Fergus M. O'Farrell, Julia J. Harris and Nicola Hamilton for comments on the manuscript.

Open Access This article is distributed under the terms of the Creative Commons Attribution License which permits any use, distribution, and reproduction in any medium, provided the original author(s) and the source are credited.

\section{References}

1. Adelman JP, Bond CT, Pessia M, Maylie J (1995) Episodic ataxia results from voltage-dependent potassium channels with altered functions. Neuron 15(6):1449-1454

2. Ahn KH, Lyoo IK, Lee HK, Song IC, Oh JS, Hwang J, Kwon J, Kim MJ, Kim M, Renshaw PF (2004) White matter hyperintensities in subjects with bipolar disorder. Psychiatry Clin Neurosci 58(5):516-521. doi:10.1111/j.1440-1819.2004.01294.x

3. Anderson GR, Galfin T, Xu W, Aoto J, Malenka RC, Sudhof TC (2012) Candidate autism gene screen identifies critical role for cell-adhesion molecule CASPR2 in dendritic arborization and spine development. Proc Natl Acad Sci USA 109(44):18120 18125. doi:10.1073/pnas.1216398109

4. Aoki Y, Abe O, Nippashi Y, Yamasue H (2013) Comparison of white matter integrity between autism spectrum disorder subjects and typically developing individuals: a meta-analysis of diffusion tensor imaging tractography studies. Mol Autism 4(1):25. doi:10.1186/2040-2392-4-25

5. Athanasiu L, Mattingsdal M, Kahler AK, Brown A, Gustafsson O, Agartz I, Giegling I, Muglia P, Cichon S, Rietschel M, Pietilainen OP, Peltonen L, Bramon E, Collier D, Clair DS, Sigurdsson E, Petursson H, Rujescu D, Melle I, Steen VM, Djurovic S, Andreassen OA (2010) Gene variants associated with schizophrenia in a Norwegian genome-wide study are replicated 
in a large European cohort. J Psychiatr Res 44(12):748-753. doi:10.1016/j.jpsychires.2010.02.002

6. Babbs CF, Shi R (2013) Subtle paranodal injury slows impulse conduction in a mathematical model of myelinated axons. PLoS One 8(7):e67767. doi:10.1371/journal.pone.0067767

7. Bakiri Y, Karadottir R, Cossell L, Attwell D (2011) Morphological and electrical properties of oligodendrocytes in the white matter of the corpus callosum and cerebellum. J Physiol 589(Pt 3):559-573. doi:10.1113/jphysiol.2010.201376

8. Barry J, Gu Y, Jukkola P, O’Neill B, Gu H, Mohler PJ, Rajamani KT, Gu C (2014) Ankyrin-G directly binds to kinesin-1 to transport voltage-gated $\mathrm{Na}$ channels into axons. Dev Cell. doi:10.1016/j.devcel.2013.11.023

9. Battefeld A, Tran BT, Gavrilis J, Cooper EC, Kole MH (2014) Heteromeric kv7.2/7.3 channels differentially regulate action potential initiation and conduction in neocortical myelinated axons. J Neurosci 34(10):3719-3732. doi:10.1523/JNEURO SCI.4206-13.2014

10. Baum AE, Akula N, Cabanero M, Cardona I, Corona W, Klemens B, Schulze TG, Cichon S, Rietschel M, Nothen MM, Georgi A, Schumacher J, Schwarz M, Abou Jamra R, Hofels S, Propping P, Satagopan J, Detera-Wadleigh SD, Hardy J, McMahon FJ (2008) A genome-wide association study implicates diacylglycerol kinase eta (DGKH) and several other genes in the etiology of bipolar disorder. Mol Psychiatry 13(2):197-207. doi :10.1038/sj.mp.4002012

11. Belloso JM, Bache I, Guitart M, Caballin MR, Halgren C, Kirchhoff M, Ropers HH, Tommerup N, Tumer Z (2007) Disruption of the CNTNAP2 gene in a $t(7 ; 15)$ translocation family without symptoms of Gilles de la Tourette syndrome. Eur J Hum Genet 15(6):711-713. doi:10.1038/sj.ejhg.5201824

12. Berger T, Rubner P, Schautzer F, Egg R, Ulmer H, Mayringer I, Dilitz E, Deisenhammer F, Reindl M (2003) Antimyelin antibodies as a predictor of clinically definite multiple sclerosis after a first demyelinating event. N Engl J Med 349(2):139-145. doi:10.1056/NEJMoa022328

13. Bhat MA, Rios JC, Lu Y, Garcia-Fresco GP, Ching W, St Martin M, Li J, Einheber S, Chesler M, Rosenbluth J, Salzer JL, Bellen HJ (2001) Axon-glia interactions and the domain organization of myelinated axons requires neurexin IV/Caspr/Paranodin. Neuron 30(2):369-383

14. Bi C, Wu J, Jiang T, Liu Q, Cai W, Yu P, Cai T, Zhao M, Jiang YH, Sun ZS (2012) Mutations of ANK3 identified by exome sequencing are associated with autism susceptibility. Hum Mutat 33(12):1635-1638. doi:10.1002/humu.22174

15. Blight AR (1989) Effect of 4-aminopyridine on axonal conduction-block in chronic spinal cord injury. Brain Res Bull 22(1):47-52

16. Boyle ME, Berglund EO, Murai KK, Weber L, Peles E, Ranscht B (2001) Contactin orchestrates assembly of the septate-like junctions at the paranode in myelinated peripheral nerve. Neuron 30(2):385-397

17. Brew HM, Gittelman JX, Silverstein RS, Hanks TD, Demas VP, Robinson LC, Robbins CA, McKee-Johnson J, Chiu SY, Messing A, Tempel BL (2007) Seizures and reduced life span in mice lacking the potassium channel subunit Kv1.2, but hypoexcitability and enlarged Kv1 currents in auditory neurons. J Neurophysiol 98(3):1501-1525. doi:10.1152/jn.00640.2006

18. Browne DL, Gancher ST, Nutt JG, Brunt ER, Smith EA, Kramer P, Litt M (1994) Episodic ataxia/myokymia syndrome is associated with point mutations in the human potassium channel gene, KCNA1. Nat Genet 8(2):136-140. doi:10.1038/ ng1094-136

19. Buttermore ED, Dupree JL, Cheng J, An X, Tessarollo L, Bhat MA (2011) The cytoskeletal adaptor protein band 4.1B is required for the maintenance of paranodal axoglial septate junctions in myelinated axons. J Neurosci 31(22):8013-8024. doi:10.1523/JNEUROSCI.1015-11.2011

20. Charles P, Tait S, Faivre-Sarrailh C, Barbin G, Gunn-Moore F, Denisenko-Nehrbass N, Guennoc AM, Girault JA, Brophy PJ, Lubetzki C (2002) Neurofascin is a glial receptor for the paranodin/Caspr-contactin axonal complex at the axoglial junction. Curr Biol 12(3):217-220

21. Chen C, Westenbroek RE, Xu X, Edwards CA, Sorenson DR, Chen Y, McEwen DP, O'Malley HA, Bharucha V, Meadows LS, Knudsen GA, Vilaythong A, Noebels JL, Saunders TL, Scheuer T, Shrager P, Catterall WA, Isom LL (2004) Mice lacking sodium channel betal subunits display defects in neuronal excitability, sodium channel expression, and nodal architecture. J Neurosci 24(16):4030-4042. doi:10.1523/JNEURO SCI.4139-03.2004

22. Chiu SY, Zhou L, Zhang CL, Messing A (1999) Analysis of potassium channel functions in mammalian axons by gene knockouts. J Neurocytol 28(4-5):349-364

23. Cifuentes-Diaz C, Chareyre F, Garcia M, Devaux J, Carnaud M, Levasseur G, Niwa-Kawakita M, Harroch S, Girault JA, Giovannini M, Goutebroze L (2011) Protein 4.1B contributes to the organization of peripheral myelinated axons. PLoS One 6(9):e25043. doi:10.1371/journal.pone.0025043

24. Coman I, Aigrot MS, Seilhean D, Reynolds R, Girault JA, Zalc B, Lubetzki C (2006) Nodal, paranodal and juxtaparanodal axonal proteins during demyelination and remyelination in multiple sclerosis. Brain 129(Pt 12):3186-3195. doi:10.1093/brain/ awl144

25. Comu S, Giuliani M, Narayanan V (1996) Episodic ataxia and myokymia syndrome: a new mutation of potassium channel gene Kv1.1. Ann Neurol 40(4):684-687. doi:10.1002/ ana.410400422

26. Craner MJ, Lo AC, Black JA, Waxman SG (2003) Abnormal sodium channel distribution in optic nerve axons in a model of inflammatory demyelination. Brain 126(Pt 7):1552-1561. doi:10.1093/brain/awg153

27. Craner MJ, Newcombe J, Black JA, Hartle C, Cuzner ML, Waxman SG (2004) Molecular changes in neurons in multiple sclerosis: altered axonal expression of Nav1.2 and Nav1.6 sodium channels and $\mathrm{Na}+/ \mathrm{Ca} 2+$ exchanger. Proc Natl Acad Sci USA 101(21):8168-8173. doi:10.1073/pnas.0402765101

28. Davis KL, Stewart DG, Friedman JI, Buchsbaum M, Harvey PD, Hof PR, Buxbaum J, Haroutunian V (2003) White matter changes in schizophrenia: evidence for myelin-related dysfunction. Arch Gen Psychiatry 60(5):443-456. doi:10.1001/archp syc.60.5.443

29. Demos MK, Macri V, Farrell K, Nelson TN, Chapman K, Accili E, Armstrong L (2009) A novel KCNA1 mutation associated with global delay and persistent cerebellar dysfunction. Mov Disord 24(5):778-782. doi:10.1002/mds.22467

30. Denisenko-Nehrbass N, Oguievetskaia K, Goutebroze L, Galvez T, Yamakawa H, Ohara O, Carnaud M, Girault JA (2003) Protein 4.1B associates with both Caspr/paranodin and Caspr2 at paranodes and juxtaparanodes of myelinated fibres. Eur $\mathrm{J}$ Neurosci 17(2):411-416

31. Desmazieres A, Zonta B, Zhang A, Wu LM, Sherman DL, Brophy PJ (2014) Differential stability of PNS and CNS nodal complexes when neuronal neurofascin is lost. J Neurosci 34(15):5083-5088. doi:10.1523/JNEUROSCI.4662-13.2014

32. Devaux J, Alcaraz G, Grinspan J, Bennett V, Joho R, Crest M, Scherer SS (2003) Kv3.1b is a novel component of CNS nodes. J Neurosci 23(11):4509-4518

33. Devaux J, Gola M, Jacquet G, Crest M (2002) Effects of K+ channel blockers on developing rat myelinated CNS axons: identification of four types of $\mathrm{K}+$ channels. J Neurophysiol 87(3):1376-1385 
34. Devaux JJ, Kleopa KA, Cooper EC, Scherer SS (2004) KCNQ2 is a nodal $\mathrm{K}+$ channel. J Neurosci 24(5):1236-1244. doi:10.152 3/JNEUROSCI.4512-03.2004

35. Duflocq A, Le Bras B, Bullier E, Couraud F, Davenne M (2008) Nav1.1 is predominantly expressed in nodes of Ranvier and axon initial segments. Mol Cell Neurosci 39(2):180-192. doi:10.1016/j.mcn.2008.06.008

36. Dupree JL, Coetzee T, Blight A, Suzuki K, Popko B (1998) Myelin galactolipids are essential for proper node of Ranvier formation in the CNS. J Neurosci 18(5):1642-1649

37. Eijkelkamp N, Linley JE, Baker MD, Minett MS, Cregg R, Werdehausen R, Rugiero F, Wood JN (2012) Neurological perspectives on voltage-gated sodium channels. Brain $135(\mathrm{Pt}$ 9):2585-2612. doi:10.1093/brain/aws225

38. Einheber S, Meng X, Rubin M, Lam I, Mohandas N, An X, Shrager P, Kissil J, Maurel P, Salzer JL (2013) The 4.1B cytoskeletal protein regulates the domain organization and sheath thickness of myelinated axons. Glia 61(2):240-253. doi:10.1002/glia.22430

39. Einheber S, Zanazzi G, Ching W, Scherer S, Milner TA, Peles E, Salzer JL (1997) The axonal membrane protein Caspr, a homologue of neurexin IV, is a component of the septate-like paranodal junctions that assemble during myelination. J Cell Biol 139(6):1495-1506

40. Elia J, Gai X, Xie HM, Perin JC, Geiger E, Glessner JT, D’Arcy M, deBerardinis R, Frackelton E, Kim C, Lantieri F, Muganga BM, Wang L, Takeda T, Rappaport EF, Grant SF, Berrettini W, Devoto M, Shaikh TH, Hakonarson H, White PS (2010) Rare structural variants found in attention-deficit hyperactivity disorder are preferentially associated with neurodevelopmental genes. Mol Psychiatry 15(6):637-646. doi:10.1038/mp.2009.57

41. Elliott C, Lindner M, Arthur A, Brennan K, Jarius S, Hussey J, Chan A, Stroet A, Olsson T, Willison H, Barnett SC, Meinl E, Linington C (2012) Functional identification of pathogenic autoantibody responses in patients with multiple sclerosis. Brain 135(Pt 6):1819-1833. doi:10.1093/brain/aws105

42. Evans MD, Sammons RP, Lebron S, Dumitrescu AS, Watkins TB, Uebele VN, Renger JJ, Grubb MS (2013) Calcineurin signaling mediates activity-dependent relocation of the axon initial segment. J Neurosci 33(16):6950-6963. doi:10.1523/JNEURO SCI.0277-13.2013

43. Grozeva D, Stone J, Nikolov I, Chambert K, Hamshere ML, Nimgaonkar VL, Moskvina V, Thase ME, Caesar S, Sachs GS, Franklin J, Gordon-Smith K, Ardlie KG, Gabriel SB, Fraser C, Blumenstiel B, Defelice M, Breen G, Gill M, Morris DW, Elkin A, Muir WJ, McGhee KA, Williamson R, MacIntyre DJ, MacLean AW, St CD, Robinson M, Van Beck M, Pereira AC, Kandaswamy R, McQuillin A, Collier DA, Bass NJ, Young AH, Lawrence J, Ferrier IN, Anjorin A, Farmer A, Curtis D, Scolnick EM, McGuffin P, Daly MJ, Corvin AP, Holmans PA, Blackwood DH, Gurling HM, Owen MJ, Purcell SM, Sklar P, Craddock N, Wellcome Trust Case Control C (2008) Collaborative genome-wide association analysis supports a role for ANK3 and CACNA1C in bipolar disorder. Nat Genet 40(9):1056-1058. doi:10.1038/ ng. 209

44. Fields RD (2008) White matter in learning, cognition and psychiatric disorders. Trends Neurosci 31(7):361-370. doi:10.1016/j.tins.2008.04.001

45. Foster RE, Connors BW, Waxman SG (1982) Rat optic nerve: electrophysiological, pharmacological and anatomical studies during development. Brain Res 255(3):371-386

46. Friedman JI, Vrijenhoek T, Markx S, Janssen IM, van der Vliet WA, Faas BH, Knoers NV, Cahn W, Kahn RS, Edelmann L, Davis KL, Silverman JM, Brunner HG, van Kessel AG, Wijmenga C, Ophoff RA, Veltman JA (2008) CNTNAP2 gene dosage variation is associated with schizophrenia and epilepsy. Mol Psychiatry 13(3):261-266. doi:10.1038/sj.mp.4002049

47. Fu Y, Frederick TJ, Huff TB, Goings GE, Miller SD, Cheng JX (2011) Paranodal myelin retraction in relapsing experimental autoimmune encephalomyelitis visualized by coherent anti-Stokes Raman scattering microscopy. J Biomed Opt 16(10):106006. doi:10.1117/1.3638180

48. Fu Y, Sun W, Shi Y, Shi R, Cheng JX (2009) Glutamate excitotoxicity inflicts paranodal myelin splitting and retraction. PLoS One 4(8):e6705. doi:10.1371/journal.pone.0006705

49. Garcia-Fresco GP, Sousa AD, Pillai AM, Moy SS, Crawley JN, Tessarollo L, Dupree JL, Bhat MA (2006) Disruption of axoglial junctions causes cytoskeletal disorganization and degeneration of Purkinje neuron axons. Proc Natl Acad Sci USA 103(13):5137-5142. doi:10.1073/pnas.0601082103

50. Gittelman JX, Tempel BL (2006) Kv1.1-containing channels are critical for temporal precision during spike initiation. J Neurophysiol 96(3):1203-1214. doi:10.1152/jn.00092.2005

51. Goodman AD, Brown TR, Krupp LB, Schapiro RT, Schwid SR, Cohen R, Marinucci LN, Blight AR, Fampridine MSFI (2009) Sustained-release oral fampridine in multiple sclerosis: a randomised, double-blind, controlled trial. Lancet 373(9665):732738. doi:10.1016/S0140-6736(09)60442-6

52. Grubb MS, Burrone J (2010) Activity-dependent relocation of the axon initial segment fine-tunes neuronal excitability. Nature 465(7301):1070-1074. doi:10.1038/nature09160

53. Gu C, Gu Y (2011) Clustering and activity tuning of Kv1 channels in myelinated hippocampal axons. J Biol Chem 286(29):25835-25847. doi:10.1074/jbc.M111.219113

54. Hansebout RR, Blight AR, Fawcett S, Reddy K (1993) 4-Aminopyridine in chronic spinal cord injury: a controlled, double-blind, crossover study in eight patients. J Neurotrauma 10(1):1-18

55. Harris JJ, Attwell D (2012) The energetics of CNS white matter. J Neurosci 32(1):356-371. doi:10.1523/JNEURO SCI.3430-11.2012

56. Hayashi A, Kaneko N, Tomihira C, Baba H (2013) Sulfatide decrease in myelin influences formation of the paranodal axoglial junction and conduction velocity in the sciatic nerve. Glia 61(4):466-474. doi:10.1002/glia.22447

57. Hayes KC, Potter PJ, Wolfe DL, Hsieh JT, Delaney GA, Blight AR (1994) 4-Aminopyridine-sensitive neurologic deficits in patients with spinal cord injury. J Neurotrauma 11(4):433-446

58. Hildebrand C (1971) Ultrastructural and light-microscopic studies of the developing feline spinal cord white matter. I. The nodes of Ranvier. Acta Physiol Scand Suppl 364:81-109

59. Hildebrand C (1971) Ultrastructural and light-microscopic studies of the nodal region in large myelinated fibres of the adult feline spinal cord white matter. Acta Physiol Scand Suppl 364:43-79

60. Hinman JD, Peters A, Cabral H, Rosene DL, Hollander W, Rasband MN, Abraham CR (2006) Age-related molecular reorganization at the node of Ranvier. J Comp Neurol 495(4):351-362. doi:10.1002/cne.20886

61. Honke K, Hirahara Y, Dupree J, Suzuki K, Popko B, Fukushima K, Fukushima J, Nagasawa T, Yoshida N, Wada Y, Taniguchi $\mathrm{N}$ (2002) Paranodal junction formation and spermatogenesis require sulfoglycolipids. Proc Natl Acad Sci USA 99(7):42274232. doi: $10.1073 /$ pnas.032068299

62. Horresh I, Bar V, Kissil JL, Peles E (2010) Organization of myelinated axons by Caspr and Caspr2 requires the cytoskeletal adapter protein 4.1B. J Neurosci 30(7):2480-2489. doi:10.1523 /JNEUROSCI.5225-09.2010

63. Horton L, Conger A, Conger D, Remington G, Frohman T, Frohman E, Greenberg B (2013) Effect of 4-aminopyridine on vision in multiple sclerosis patients with optic neuropathy. 
Neurology 80(20):1862-1866. doi:10.1212/WNL.0b013e31829 $29 \mathrm{fd} 5$

64. Howell OW, Palser A, Polito A, Melrose S, Zonta B, Scheiermann C, Vora AJ, Brophy PJ, Reynolds R (2006) Disruption of neurofascin localization reveals early changes preceding demyelination and remyelination in multiple sclerosis. Brain $129(\mathrm{Pt}$ 12):3173-3185. doi:10.1093/brain/awl290

65. Howell OW, Rundle JL, Garg A, Komada M, Brophy PJ, Reynolds R (2010) Activated microglia mediate axoglial disruption that contributes to axonal injury in multiple sclerosis. J Neuropathol Exp Neurol 69(10):1017-1033. doi:10.1097/NEN.0b013 e3181f3a5b1

66. Iqbal Z, Vandeweyer G, van der Voet M, Waryah AM, Zahoor MY, Besseling JA, Roca LT, Vulto-van Silfhout AT, Nijhof B, Kramer JM, Van der Aa N, Ansar M, Peeters H, Helsmoortel C, Gilissen C, Vissers LE, Veltman JA, de Brouwer AP, Frank Kooy R, Riazuddin S, Schenck A, van Bokhoven H, Rooms L (2013) Homozygous and heterozygous disruptions of ANK3: at the crossroads of neurodevelopmental and psychiatric disorders. Hum Mol Genet 22(10):1960-1970. doi:10.1093/hmg/ddt043

67. Ishibashi T, Dupree JL, Ikenaka K, Hirahara Y, Honke K, Peles E, Popko B, Suzuki K, Nishino H, Baba H (2002) A myelin galactolipid, sulfatide, is essential for maintenance of ion channels on myelinated axon but not essential for initial cluster formation. J Neurosci 22(15):6507-6514

68. Jarjour AA, Bull SJ, Almasieh M, Rajasekharan S, Baker KA, Mui J, Antel JP, Di Polo A, Kennedy TE (2008) Maintenance of axo-oligodendroglial paranodal junctions requires DCC and netrin-1. J Neurosci 28(43):11003-11014. doi:10.1523/JNEUR OSCI.3285-08.2008

69. Jensen JM, Shi R (2003) Effects of 4-aminopyridine on stretched mammalian spinal cord: the role of potassium channels in axonal conduction. J Neurophysiol 90(4):2334-2340. doi:10.1152/jn.00868.2002

70. Jia P, Ewers JM, Zhao Z (2011) Prioritization of epilepsy associated candidate genes by convergent analysis. PLoS One 6(2):e17162. doi:10.1371/journal.pone.0017162

71. Judge SI, Bever CT Jr (2006) Potassium channel blockers in multiple sclerosis: neuronal $\mathrm{Kv}$ channels and effects of symptomatic treatment. Pharmacol Ther 111(1):224-259. doi:10.1016/j.pharmthera.2005.10.006

72. Judy JT, Seifuddin F, Pirooznia M, Mahon PB, Bipolar Genome Study C, Jancic D, Goes FS, Schulze T, Cichon S, Noethen M, Rietschel M, Depaulo JR, Potash JB, Zandi PP (2013) Converging evidence for epistasis between ANK3 and potassium channel gene KCNQ2 in bipolar disorder. Front Genet 4:87. doi:10.3 389/fgene.2013.00087

73. Kleopa KA, Elman LB, Lang B, Vincent A, Scherer SS (2006) Neuromyotonia and limbic encephalitis sera target mature Shaker-type $\mathrm{K}+$ channels: subunit specificity correlates with clinical manifestations. Brain 129(Pt 6):1570-1584. doi:10.1093/brain/awl084

74. Koch T, Brugger T, Bach A, Gennarini G, Trotter J (1997) Expression of the immunoglobulin superfamily cell adhesion molecule F3 by oligodendrocyte-lineage cells. Glia 19(3):199-212

75. Kocsis JD, Ruiz JA, Waxman SG (1983) Maturation of mammalian myelinated fibers: changes in action-potential characteristics following 4-aminopyridine application. J Neurophysiol 50(2):449-463

76. Kocsis JD, Waxman SG (1980) Absence of potassium conductance in central myelinated axons. Nature 287(5780):348-349

77. Kopp-Scheinpflug C, Fuchs K, Lippe WR, Tempel BL, Rubsamen R (2003) Decreased temporal precision of auditory signaling in Kcna1-null mice: an electrophysiological study in vivo. J Neurosci 23(27):9199-9207
78. Kuba H, Oichi Y, Ohmori H (2010) Presynaptic activity regulates $\mathrm{Na}^{+}$channel distribution at the axon initial segment. Nature 465(7301):1075-1078. doi:10.1038/nature09087

79. Labasque M, Faivre-Sarrailh C (2010) GPI-anchored proteins at the node of Ranvier. FEBS Lett 584(9):1787-1792. doi:10.1016/j.febslet.2009.08.025

80. Landaas ET, Johansson S, Halmoy A, Oedegaard KJ, Fasmer OB, Haavik J (2011) Bipolar disorder risk alleles in adult ADHD patients. Genes Brain Behav 10(4):418-423. doi:10.1111/j.1601-183X.2011.00680.x

81. Lawrence JJ, Saraga F, Churchill JF, Statland JM, Travis KE, Skinner FK, McBain CJ (2006) Somatodendritic Kv7/KCNQ/M channels control interspike interval in hippocampal interneurons. J Neurosci 26(47):12325-12338. doi:10.1523/JNEURO SCI.3521-06.2006

82. Lee S, Leach MK, Redmond SA, Chong SY, Mellon SH, Tuck SJ, Feng ZQ, Corey JM, Chan JR (2012) A culture system to study oligodendrocyte myelination processes using engineered nanofibers. Nat Methods 9(9):917-922. doi:10.1038/nm eth. 2105

83. Liguori R, Avoni P, Baruzzi A, Di Stasi V, Montagna P (2001) Familial continuous motor unit activity and epilepsy. Muscle Nerve 24(5):630-633

84. Lorincz A, Nusser Z (2010) Molecular identity of dendritic voltage-gated sodium channels. Science 328(5980):906-909. doi:10.1126/science. 1187958

85. Maier O, Baron W, Hoekstra D (2007) Reduced raft-association of NF155 in active MS-lesions is accompanied by the disruption of the paranodal junction. Glia 55(8):885-895. doi:10.1002/ glia. 20510

86. Maier-Hein KH, Brunner R, Lutz K, Henze R, Parzer P, Feigl N, Kramer J, Meinzer HP, Resch F, Stieltjes B (2014) Disorder-specific white matter alterations in adolescent borderline personality disorder. Biol Psychiatry 75(1):81-88. doi:10.1016/j.biopsych.2013.03.031

87. Maljevic S, Wuttke TV, Seebohm G, Lerche H (2010) KV7 channelopathies. Pflugers Arch 460(2):277-288. doi:10.1007/ s00424-010-0831-3

88. Marella M, Patki G, Matsuno-Yagi A, Yagi T (2013) Complex I inhibition in the visual pathway induces disorganization of the node of Ranvier. Neurobiol Dis 58:281-288. doi:10.1016/j.nbd.2013.06.010

89. Mathey EK, Derfuss T, Storch MK, Williams KR, Hales K, Woolley DR, Al-Hayani A, Davies SN, Rasband MN, Olsson T, Moldenhauer A, Velhin S, Hohlfeld R, Meinl E, Linington C (2007) Neurofascin as a novel target for autoantibody-mediated axonal injury. J Exp Med 204(10):2363-2372. doi:10.1084/jem.20071053

90. Mefford HC, Muhle H, Ostertag P, von Spiczak S, Buysse K, Baker C, Franke A, Malafosse A, Genton P, Thomas P, Gurnett CA, Schreiber S, Bassuk AG, Guipponi M, Stephani U, Helbig I, Eichler EE (2010) Genome-wide copy number variation in epilepsy: novel susceptibility loci in idiopathic generalized and focal epilepsies. PLoS Genet 6(5):e1000962. doi:10.1371/ journal.pgen.1000962

91. Moll C, Mourre C, Lazdunski M, Ulrich J (1991) Increase of sodium channels in demyelinated lesions of multiple sclerosis. Brain Res 556(2):311-316

92. Nans A, Einheber S, Salzer JL, Stokes DL (2011) Electron tomography of paranodal septate-like junctions and the associated axonal and glial cytoskeletons in the central nervous system. J Neurosci Res 89(3):310-319. doi:10.1002/jnr.22561

93. Nashmi R, Fehlings MG (2001) Mechanisms of axonal dysfunction after spinal cord injury: with an emphasis on the role of voltage-gated potassium channels. Brain Res Brain Res Rev $38(1-2): 165-191$ 
94. Nave KA (2010) Myelination and support of axonal integrity by glia. Nature 468(7321):244-252. doi:10.1038/nature09614

95. Nave KA, Trapp BD (2008) Axon-glial signaling and the glial support of axon function. Annu Rev Neurosci 31:535-561. doi: 10.1146/annurev.neuro.30.051606.094309

96. Nazeri A, Chakravarty MM, Felsky D, Lobaugh NJ, Rajji TK, Mulsant BH, Voineskos AN (2013) Alterations of superficial white matter in schizophrenia and relationship to cognitive performance. Neuropsychopharmacology 38(10):1954-1962. doi:1 0.1038/npp.2013.93

97. O’Dushlaine C, Kenny E, Heron E, Donohoe G, Gill M, Morris D, International Schizophrenia C, Corvin A (2011) Molecular pathways involved in neuronal cell adhesion and membrane scaffolding contribute to schizophrenia and bipolar disorder susceptibility. Mol Psychiatry 16(3):286-292. doi:10.1038/mp.2010.7

98. Ogawa Y, Oses-Prieto J, Kim MY, Horresh I, Peles E, Burlingame AL, Trimmer JS, Meijer D, Rasband MN (2010) ADAM22, a Kv1 channel-interacting protein, recruits membrane-associated guanylate kinases to juxtaparanodes of myelinated axons. J Neurosci 30(3):1038-1048. doi:10.1523/JNEUR OSCI.4661-09.2010

99. Ogawa Y, Rasband MN (2009) Proteomic analysis of optic nerve lipid rafts reveals new paranodal proteins. J Neurosci Res 87(15):3502-3510. doi:10.1002/jnr.21984

100. Ogawa Y, Schafer DP, Horresh I, Bar V, Hales K, Yang Y, Susuki K, Peles E, Stankewich MC, Rasband MN (2006) Spectrins and ankyrinB constitute a specialized paranodal cytoskeleton. J Neurosci 26(19):5230-5239. doi:10.1523/JNEURO SCI.0425-06.2006

101. Ouyang H, Sun W, Fu Y, Li J, Cheng JX, Nauman E, Shi $R$ (2010) Compression induces acute demyelination and potassium channel exposure in spinal cord. J Neurotrauma 27(6):1109-1120. doi:10.1089/neu.2010.1271

102. Ozkaynak E, Abello G, Jaegle M, van Berge L, Hamer D, Kegel L, Driegen S, Sagane K, Bermingham JR Jr, Meijer D (2010) Adam22 is a major neuronal receptor for Lgi4-mediated Schwann cell signaling. J Neurosci 30(10):3857-3864. doi:10.1 523/JNEUROSCI.6287-09.2010

103. Peles E, Nativ M, Campbell PL, Sakurai T, Martinez R, Lev S, Clary DO, Schilling J, Barnea G, Plowman GD, Grumet M, Schlessinger J (1995) The carbonic anhydrase domain of receptor tyrosine phosphatase beta is a functional ligand for the axonal cell recognition molecule contactin. Cell 82(2):251-260

104. Peles E, Nativ M, Lustig M, Grumet M, Schilling J, Martinez R, Plowman GD, Schlessinger J (1997) Identification of a novel contactin-associated transmembrane receptor with multiple domains implicated in protein-protein interactions. EMBO J 16(5):978-988. doi:10.1093/emboj/16.5.978

105. Peters SU, Horowitz L, Barbieri-Welge R, Taylor JL, Hundley RJ (2012) Longitudinal follow-up of autism spectrum features and sensory behaviors in Angelman syndrome by deletion class. J Child Psychol Psychiatry 53(2):152-159. doi:10.1111/j.1469-7610.2011.02455.x

106. Pillai AM, Thaxton C, Pribisko AL, Cheng JG, Dupree JL, Bhat MA (2009) Spatiotemporal ablation of myelinating gliaspecific neurofascin (Nfasc NF155) in mice reveals gradual loss of paranodal axoglial junctions and concomitant disorganization of axonal domains. J Neurosci Res 87(8):1773-1793. doi:10.1002/jnr.22015

107. Poliak S, Salomon D, Elhanany H, Sabanay H, Kiernan B, Pevny L, Stewart CL, Xu X, Chiu SY, Shrager P, Furley AJ, Peles E (2003) Juxtaparanodal clustering of Shaker-like K+ channels in myelinated axons depends on Caspr2 and TAG-1. J Cell Biol 162(6):1149-1160. doi:10.1083/jcb.200305018
108. Popko B (2000) Myelin galactolipids: mediators of axon-glial interactions? Glia 29(2):149-153

109. Rasband MN (2010) The axon initial segment and the maintenance of neuronal polarity. Nat Rev Neurosci 11(8):552-562. doi: $10.1038 / \mathrm{nrn} 2852$

110. Rasband MN (2011) Composition, assembly, and maintenance of excitable membrane domains in myelinated axons. Semin Cell Dev Biol 22(2):178-184. doi:10.1016/j.semcdb.2010.09.010

111. Rasband MN, Peles E, Trimmer JS, Levinson SR, Lux SE, Shrager P (1999) Dependence of nodal sodium channel clustering on paranodal axoglial contact in the developing CNS. J Neurosci 19(17):7516-7528

112. Rasband MN, Trimmer JS, Peles E, Levinson SR, Shrager P (1999) $\mathrm{K}+$ channel distribution and clustering in developing and hypomyelinated axons of the optic nerve. J Neurocytol 28(4-5):319-331

113. Rasband MN, Trimmer JS, Schwarz TL, Levinson SR, Ellisman MH, Schachner M, Shrager P (1998) Potassium channel distribution, clustering, and function in remyelinating rat axons. J Neurosci 18(1):36-47

114. Reimer MM, McQueen J, Searcy L, Scullion G, Zonta B, Desmazieres A, Holland PR, Smith J, Gliddon C, Wood ER, Herzyk P, Brophy PJ, McCulloch J, Horsburgh K (2011) Rapid disruption of axon-glial integrity in response to mild cerebral hypoperfusion. J Neurosci 31(49):18185-18194. doi:10.1523/J NEUROSCI.4936-11.2011

115. Reindl M, Linington C, Brehm U, Egg R, Dilitz E, Deisenhammer F, Poewe W, Berger T (1999) Antibodies against the myelin oligodendrocyte glycoprotein and the myelin basic protein in multiple sclerosis and other neurological diseases: a comparative study. Brain 122(Pt 11):2047-2056

116. Rios JC, Melendez-Vasquez CV, Einheber S, Lustig M, Grumet M, Hemperly J, Peles E, Salzer JL (2000) Contactin-associated protein (Caspr) and contactin form a complex that is targeted to the paranodal junctions during myelination. J Neurosci 20(22):8354-8364

117. Rios JC, Rubin M, St Martin M, Downey RT, Einheber S, Rosenbluth J, Levinson SR, Bhat M, Salzer JL (2003) Paranodal interactions regulate expression of sodium channel subtypes and provide a diffusion barrier for the node of Ranvier. J Neurosci 23(18):7001-7011

118. Ritter J, Schmitz T, Chew LJ, Buhrer C, Mobius W, Zonouzi M, Gallo V (2013) Neonatal hyperoxia exposure disrupts axon-oligodendrocyte integrity in the subcortical white matter. J Neurosci 33(21):8990-9002. doi:10.1523/JNEUROSCI.5528-12.2013

119. Rosenbluth J (1987) Abnormal axoglial junctions in the myelindeficient rat mutant. J Neurocytol 16(4):497-509

120. Rosenbluth J (2009) Multiple functions of the paranodal junction of myelinated nerve fibers. J Neurosci Res 87(15):3250 3258. doi:10.1002/jnr.22013

121. Roussos P, Katsel P, Davis KL, Bitsios P, Giakoumaki SG, Jogia J, Rozsnyai K, Collier D, Frangou S, Siever LJ, Haroutunian V (2012) Molecular and genetic evidence for abnormalities in the nodes of Ranvier in schizophrenia. Arch Gen Psychiatry 69(1):7-15. doi:10.1001/archgenpsychiatry.2011.110

122. Salzer JL, Brophy PJ, Peles E (2008) Molecular domains of myelinated axons in the peripheral nervous system. Glia 56(14):1532-1540. doi:10.1002/glia.20750

123. Savvaki M, Panagiotaropoulos T, Stamatakis A, Sargiannidou I, Karatzioula P, Watanabe K, Stylianopoulou F, Karagogeos D, Kleopa KA (2008) Impairment of learning and memory in TAG-1 deficient mice associated with shorter CNS internodes and disrupted juxtaparanodes. Mol Cell Neurosci 39(3):478490. doi:10.1016/j.mcn.2008.07.025 
124. Schaeren-Wiemers N, Bonnet A, Erb M, Erne B, Bartsch U, Kern F, Mantei N, Sherman D, Suter U (2004) The raft-associated protein MAL is required for maintenance of proper axon-glia interactions in the central nervous system. J Cell Biol 166(5):731-742. doi:10.1083/jcb.200406092

125. Schizophrenia Psychiatric Genome-Wide Association Study C (2011) Genome-wide association study identifies five new schizophrenia loci. Nat Genet 43(10):969-976. doi:10.1038/ng.940

126. Schniepp R, Jakl V, Wuehr M, Havla J, Kumpfel T, Dieterich M, Strupp M, Jahn K (2013) Treatment with 4-aminopyridine improves upper limb tremor of a patient with multiple sclerosis: a video case report. Mult Scler 19(4):506-508. doi:10.1177/1352458512461394

127. Schulze TG, Detera-Wadleigh SD, Akula N, Gupta A, Kassem L, Steele J, Pearl J, Strohmaier J, Breuer R, Schwarz M, Propping P, Nothen MM, Cichon S, Schumacher J, Consortium NGIBD, Rietschel M, McMahon FJ (2009) Two variants in Ankyrin 3 (ANK3) are independent genetic risk factors for bipolar disorder. Mol Psychiatry 14(5):487-491

128. Seidl AH (2013) Regulation of conduction time along axons. Neuroscience. doi:10.1016/j.neuroscience.2013.06.047

129. Sherman DL, Tait S, Melrose S, Johnson R, Zonta B, Court FA, Macklin WB, Meek S, Smith AJ, Cottrell DF, Brophy PJ (2005) Neurofascins are required to establish axonal domains for saltatory conduction. Neuron 48(5):737-742. doi:10.1016/j. neuron.2005.10.019

130. Shi R, Blight AR (1997) Differential effects of low and high concentrations of 4-aminopyridine on axonal conduction in normal and injured spinal cord. Neuroscience 77(2):553-562

131. Sinha K, Karimi-Abdolrezaee S, Velumian AA, Fehlings MG (2006) Functional changes in genetically dysmyelinated spinal cord axons of shiverer mice: role of juxtaparanodal Kv1 family K+ channels. J Neurophysiol 95(3):1683-1695. doi:10.1152 /jn.00899.2005

132. Smart SL, Lopantsev V, Zhang CL, Robbins CA, Wang H, Chiu SY, Schwartzkroin PA, Messing A, Tempel BL (1998) Deletion of the $\mathrm{K}(\mathrm{V}) 1.1$ potassium channel causes epilepsy in mice. Neuron 20(4):809-819

133. Smith KJ, Felts PA, John GR (2000) Effects of 4-aminopyridine on demyelinated axons, synapses and muscle tension. Brain 123(Pt 1):171-184

134. Sozmen EG, Hinman JD, Carmichael ST (2012) Models that matter: white matter stroke models. Neurotherapeutics 9(2):349-358. doi:10.1007/s13311-012-0106-0

135. Stogmann E, Reinthaler E, Eltawil S, El Etribi MA, Hemeda M, El Nahhas N, Gaber AM, Fouad A, Edris S, Benet-Pages A, Eck SH, Pataraia E, Mei D, Brice A, Lesage S, Guerrini R, Zimprich F, Strom TM, Zimprich A (2013) Autosomal recessive cortical myoclonic tremor and epilepsy: association with a mutation in the potassium channel associated gene CNTN2. Brain $136(\mathrm{Pt}$ 4):1155-1160. doi:10.1093/brain/awt068

136. Sun J, Link H, Olsson T, Xiao BG, Andersson G, Ekre HP, Linington C, Diener P (1991) T and B cell responses to myelinoligodendrocyte glycoprotein in multiple sclerosis. J Immunol 146(5):1490-1495

137. Sun JB, Olsson T, Wang WZ, Xiao BG, Kostulas V, Fredrikson S, Ekre HP, Link H (1991) Autoreactive T and B cells responding to myelin proteolipid protein in multiple sclerosis and controls. Eur J Immunol 21(6):1461-1468. doi:10.1002/ eji. 1830210620

138. Sun W, Fu Y, Shi Y, Cheng JX, Cao P, Shi R (2012) Paranodal myelin damage after acute stretch in Guinea pig spinal cord. J Neurotrauma 29(3):611-619. doi:10.1089/neu.2011.2086

139. Susuki K (2013) Node of Ranvier disruption as a cause of neurological diseases. ASN Neuro 5(3):209-219. doi:10.1042/ AN20130025
140. Susuki K, Baba H, Tohyama K, Kanai K, Kuwabara S, Hirata K, Furukawa K, Furukawa K, Rasband MN, Yuki N (2007) Gangliosides contribute to stability of paranodal junctions and ion channel clusters in myelinated nerve fibers. Glia 55(7):746757. doi:10.1002/glia.20503

141. Susuki K, Chang KJ, Zollinger DR, Liu Y, Ogawa Y, EshedEisenbach Y, Dours-Zimmermann MT, Oses-Prieto JA, Burlingame AL, Seidenbecher CI, Zimmermann DR, Oohashi T, Peles E, Rasband MN (2013) Three mechanisms assemble central nervous system nodes of Ranvier. Neuron 78(3):469-482. doi:10.1016/j.neuron.2013.03.005

142. Tagoe T, Barker M, Jones A, Allcock N, Hamann M (2014) Auditory nerve perinodal dysmyelination in noise-induced hearing loss. J Neurosci 34(7):2684-2688. doi:10.1523/JNEUR OSCI.3977-13.2014

143. Tait S, Gunn-Moore F, Collinson JM, Huang J, Lubetzki C, Pedraza L, Sherman DL, Colman DR, Brophy PJ (2000) An oligodendrocyte cell adhesion molecule at the site of assembly of the paranodal axo-glial junction. J Cell Biol 150(3):657-666

144. Tighe SK, Reading SA, Rivkin P, Caffo B, Schweizer B, Pearlson G, Potash JB, Depaulo JR, Bassett SS (2012) Total white matter hyperintensity volume in bipolar disorder patients and their healthy relatives. Bipolar Disord 14(8):888-893. doi:10.1111/bdi.12019

145. Traka M, Goutebroze L, Denisenko N, Bessa M, Nifli A, Havaki S, Iwakura Y, Fukamauchi F, Watanabe K, Soliven B, Girault JA, Karagogeos D (2003) Association of TAG-1 with Caspr2 is essential for the molecular organization of juxtaparanodal regions of myelinated fibers. J Cell Biol 162(6):1161-1172. doi $: 10.1083 / \mathrm{jcb} .200305078$

146. Trapp BD, Nave KA (2008) Multiple sclerosis: an immune or neurodegenerative disorder? Annu Rev Neurosci 31:247-269. doi:10.1146/annurev.neuro.30.051606.094313

147. Ullen F (2009) Is activity regulation of late myelination a plastic mechanism in the human nervous system? Neuron Glia Biol 5(1-2):29-34. doi:10.1017/S1740925X09990330

148. Vabnick I, Trimmer JS, Schwarz TL, Levinson SR, Risal D, Shrager P (1999) Dynamic potassium channel distributions during axonal development prevent aberrant firing patterns. J Neurosci 19(2):747-758

149. Vacher H, Mohapatra DP, Trimmer JS (2008) Localization and targeting of voltage-dependent ion channels in mammalian central neurons. Physiol Rev 88(4):1407-1447. doi:10.1152/phys rev.00002.2008

150. Wallstrom E, Khademi M, Andersson M, Weissert R, Linington C, Olsson T (1998) Increased reactivity to myelin oligodendrocyte glycoprotein peptides and epitope mapping in HLA DR2(15)+ multiple sclerosis. Eur J Immunol 28(10):3329_ 3335. doi:10.1002/(SICI)1521-4141(199810)28:10<3329:AIDIMMU3329>3.0.CO;2-B

151. Wang H, Kunkel DD, Martin TM, Schwartzkroin PA, Tempel BL (1993) Heteromultimeric K+ channels in terminal and juxtaparanodal regions of neurons. Nature 365(6441):75-79. doi: $10.1038 / 365075 \mathrm{a} 0$

152. Wang J, Li QH, Dong WJ, Chen JS (1993) Effects of $\mathrm{K}^{+}$channel blockers on cochlear potentials in the guinea pig. Hear Res 68(2):152-158

153. Waxman SG, Pappas GD, Bennett MVL (1972) Morphological correlates of functional differentiation of nodes of Ranvier along single fibers in the neurogenic electric organ of the knife fish Sternarchus. J Cell Biol 53:210-224

154. Wolswijk G, Balesar R (2003) Changes in the expression and localization of the paranodal protein Caspr on axons in chronic multiple sclerosis. Brain 126(Pt 7):1638-1649. doi:10.1093/ brain/awg 151

155. Xiao BG, Linington C, Link H (1991) Antibodies to myelinoligodendrocyte glycoprotein in cerebrospinal fluid from 
patients with multiple sclerosis and controls. J Neuroimmunol 31(2):91-96

156. Xie G, Harrison J, Clapcote SJ, Huang Y, Zhang JY, Wang LY, Roder JC (2010) A new Kv1.2 channelopathy underlying cerebellar ataxia. J Biol Chem 285(42):32160-32173. doi:10.1074/jbc.M110.153676

157. Xu K, Zhong G, Zhuang X (2013) Actin, spectrin, and associated proteins form a periodic cytoskeletal structure in axons. Science 339(6118):452-456. doi:10.1126/science.1232251

158. Zhang Y, Bekku Y, Dzhashiashvili Y, Armenti S, Meng X, Sasaki Y, Milbrandt J, Salzer JL (2012) Assembly and maintenance of nodes of Ranvier rely on distinct sources of proteins and targeting mechanisms. Neuron 73(1):92-107. doi:10.1016/j. neuron.2011.10.016
159. Zonta B, Tait S, Melrose S, Anderson H, Harroch S, Higginson J, Sherman DL, Brophy PJ (2008) Glial and neuronal isoforms of Neurofascin have distinct roles in the assembly of nodes of Ranvier in the central nervous system. J Cell Biol 181(7):11691177. doi:10.1083/jcb.200712154

160. Zuberi SM, Eunson LH, Spauschus A, De Silva R, Tolmie J, Wood NW, McWilliam RC, Stephenson JB, Kullmann DM, Hanna MG (1999) A novel mutation in the human voltagegated potassium channel gene (Kv1.1) associates with episodic ataxia type 1 and sometimes with partial epilepsy. Brain 122(Pt 5):817-825 